\title{
Risk Evaluation of Seven Personal Care Detergents Based on Chemical and Ecotoxicological Characterization in Synthetic Aqueous Media
}

\author{
Oguz Kizek $^{1}$, Deniz İzlen Çifçii ${ }^{1}$, Füsun Ekmekyapar ${ }^{1, *}$, Antonietta Siciliano $^{2}$, Sureyya Meriç ${ }^{1}$ \\ ${ }^{\mathbf{1}}$ Department of Environmental Engineering, Faculty of Corlu Engineering, Namik Kemal University, Turkey \\ ${ }^{2}$ Department of Biology, Ecotoxicology Research Laboratory, Naples University, Italy
}

Copyright $\mathrm{C} 2017$ by authors, all rights reserved. Authors agree that this article remains permanently open access under the terms of the Creative Commons Attribution License 4.0 International License

\begin{abstract}
Personal care products (PCPs), composed of various chemicals as complex mixture nature, are evaluated among those MPs found often in treated sewage and greywater. Among PCPs, detergents (PCDs) are forming specific complex mixtures containing various endocrine disruptor chemicals, to be handled accurately. In this study, acute toxicity of seven PCDs including shampoos (4) and shower gels (3) collected from different Hotels located in different countries was investigated. Chemical characterization (Chemical oxygen demand, COD; Total organic carbon, TOC) was performed according to Standard Methods. Besides, absorbance spectrum of each PCD was screened using UV-vis instrument. Acute toxicity of synthetic solutions prepared by dissolving PCDs in distilled water was assessed on two freshwater crustaceans Daphnia magna (D. magna) and Ceriodaphnia dubia (C. dubia) according to ISO 6341 Method. Acute toxicity was assessed for 24 and $48 \mathrm{~h}$ of exposure time by dividing the number of immobile organisms by total tested organisms (20) to score immobilization percentiles of each sample tested. By this way it was possible to calculate the concentration of $\mathrm{EC}_{50}$ indicating a 50\% population immobilization, using PROBIT program. The results of chemical characterization showed that the biodegradability by means of TOC/COD ratio of PCDs was very low. C. dubia was observed to be more sensitive than D. magna regarding lower values of $\mathrm{EC}_{50}$. All tested chemicals were found to be harmful according to $\mathrm{EC}_{50}$ toxic chemical's evaluation scoring system.
\end{abstract}

Keywords Acute Toxicity, Ceriodaphnia dubia, Daphnia magna, Personal Care Detergents (PCDs), Risk Evaluation

\section{Introduction}

PCDs are widely used in everyday for personal care and as household products as well as in a variety of industrial applications. As a result, large amounts of products are commonly discharged in large quantities to sewage treatment plants or directly to the aquatic environment areas where there are no sewage treatments [1-2]. PCDs are a diverse group of compounds used in soaps, lotions, toothpaste, fragrances, and sunscreens. The primary classes of PCDs include disinfectants (e.g. triclosan), fragrances (e.g. masks), insect repellants (e.g. DEET), preservatives (e.g. parabens) and UV filters (e.g. methylbenzylidene camphor). PCDs are products intended for external use on the human body and thus are not subjected to metabolic alterations; therefore, large quantities of PCDs enter the environment unaltered through regular usage. Many of these compounds are used in large quantities, and recent studies have indicated many are environmentally persistent, bioactive, and have the potential for bioaccumulation [3]. Environmental fate and effect datasets of many ingredients used in personal care detergents (PCDs) are still limited. There is emerging focus on the use of a number of substances classified under this category, including the nitro- and polycyclic musk, UV blockers such as methylbenzylidene camphor, and preservatives such as the parabens, therefore, methods for prioritizing the environmental risk assessment for chemicals used in PCDs are needed [4]. PCDs which contain surfactants, can seriously damage the environment. The surfactant toxicity is primarily a function of the ability of the surfactant to adsorb and penetrate the cell membrane of aquatic organisms [5]. Lewis [6] summarized the chronic and sub-lethal toxicities of surfactants to aquatic animals and found that chronic toxicity of anionic and nonionic surfactants occurs at concentrations usually greater than 0.1 $\mathrm{mg} / \mathrm{L}$. Deleterious effects caused by surfactants have been reported in studies with D. magna and Vibrio fischeri [4], micro-crustaceans [7, 8], algae-crustaceans-fish [9]. Table 1 shows a set of acute toxicity test results of several compounds present in personal care products while Table 2 
displays chronic toxicity of those compounds to several aquatic organisms [3].

There is a European Commission Decision (L186/36) for establishing ecological criteria for the award of the Community Eco-label to soaps, shampoos and hair conditioners [22]. The text makes reference to the Detergent Ingredient Database (DID list), which contains many of the most widely used ingredients in soap and shampoo formulations. Part A of DID list is used for deriving the data for the calculations of the CDV that is calculated for each ingredient (i) and for the whole product using the equations 1 and 2:

$$
\mathrm{CDV}(\text { ingredient } \mathrm{i})=\text { weight }(\mathrm{i})
$$$$
\text { (i) } \times \mathrm{DF}(\mathrm{i}) \times 1000 / \mathrm{TF} \text { chronic (i) }
$$

$$
\mathrm{CDV}=\Sigma \mathrm{CDV}(\text { ingredient } \mathrm{i})
$$

where weight (i) is the weight of the ingredient (in grams) per functional unit. DF (i) is the degradation factor and TF chronic (i) is the toxicity factor of the ingredient (in mg. $\mathrm{L}^{-1}$ ). The values of DF and TF chronic should be as given in the DID list-part A. The CDV(tox) is summed for each ingredient, making the CDV for the product. For ingredients not included in the DID-list, test results and test methods for ecotoxicity (long-term effects (NOEC data) on fish, $D$. magna, and algae), biodegradation and bioaccumulation should be submitted. If the lowest toxicity is $\leq 10 \mathrm{mg}$. $\mathrm{L}^{-1}$, then test results for potential bioaccumulation (Bio-concentration factor (BCF) or logKow) must also be given. 
Table 1. Acute toxicity data for personal care products [Adopted from 3]

\begin{tabular}{|c|c|c|c|c|c|c|c|}
\hline Compound & Category & Species & Trophic group & Endpoint/duration & $\mathrm{LC}_{50}\left(\mathrm{mg} \cdot \mathrm{L}^{-1}\right)$ & Additional tox. values & Ref. \\
\hline \multirow[t]{2}{*}{ Triclosan } & Antimicrobial & D.magna & Invert & $48 \mathrm{~h}$ & 0.39 & & Orvos et al. [10] \\
\hline & & Oryzias latipes & Fish & $96 \mathrm{~h}$ & 0.602 (larvae), 0.399 (embryos) & & Ishibashi et al. [11] \\
\hline Triclocarban & Antimicrobial & P.subcapitata & Algae & $72 \mathrm{~h}$ Growth & $>$ Sol & & Yang et al. [12] \\
\hline \multirow[t]{3}{*}{ Musk ketone } & Nitro musk & V.fischeri & Bacteria & Microtox & $>1.0$ & & Schramm et al. [13] \\
\hline & & Nitocra spinipes & Invert & $96 \mathrm{~h}$ & 1.32 & $\mathrm{LC}_{10}=0.40$ & Breitholtz et al. [14] \\
\hline & & P.subcapitata & Algae & $72 \mathrm{~h}$ & & & Schramm et al. [13] \\
\hline \multirow[t]{6}{*}{ Propylparaben } & Preservative & T.thermophila & Protozoa & $24 \mathrm{~h}, 28 \mathrm{~h}$ & $9.7,12.5$ & $\mathrm{LOEC}=2.6$ & Bazin et al. [15] \\
\hline & & V.fischeri & Bacteria & 15 min, 30 min Luminescence & $2.5,2.6$ & LOEC $=0.9$ & Bazin et al. [15] \\
\hline & & P.leognathi & Bacteria & $15 \mathrm{~min}, 30 \mathrm{~min}$ Luminescence & 21,25 & LOEC $=4.5$ & Bazin et al. [15] \\
\hline & & D.magna & Invert & $48 \mathrm{~h}$ & 12.3 & & Dobbins et al. [16] \\
\hline & & D.magna & Invert & 24 h, 48 h Mobility & 13.7 & $\mathrm{LOEC}=6$ & Breitholtz et al. [14] \\
\hline & & Pimephales promelas & Fish & $48 \mathrm{~h}$ & 9.7 & & Bazin et al. [15] \\
\hline
\end{tabular}

Table 2. Chronic toxicity data for personal care products [Adopted from 3]

\begin{tabular}{|c|c|c|c|c|c|c|c|}
\hline Compound & Category & Species & Trophic level & Endpoint/duration & $\begin{array}{c}\text { LOEC } \\
\left(\mu \mathrm{g} . \mathrm{L}^{-1}\right) \\
\end{array}$ & $\begin{array}{l}\text { NOEC } \\
\left(\mu \mathrm{g} . \mathrm{L}^{-1}\right)\end{array}$ & Reference \\
\hline \multirow[t]{6}{*}{ Triclosan } & Antimicrobial & D.magna & Invert & 21 d Survival, Reproduction & Reproduction $=200$ & Survival $=200$ & Orvos et al. [10] \\
\hline & & C. dubia & Invert & 7 d Survival, Reproduction & & 50,6 & Orvos et al. [10] \\
\hline & & Chironomus tentans & Invert & $10 \mathrm{~d}$ Survival, Growth & $\mathrm{LC} 25=100$ & & Dussault et al. [17] \\
\hline & & Hyalella azteca & Invert & 10 d Survival, Growth & $\mathrm{LC} 25=60$ & & Dussault et al. [17] \\
\hline & & Natural algal & Algae & $96 \mathrm{~h}$ Biomass & 0.12 & & Wilson et al. [18] \\
\hline & & D. tertiolecta & Algae & 96 h Growth & & 1.6 & De Lorenzo et al. [19] \\
\hline \multirow[t]{2}{*}{ Musk ketone } & Nitro musk & A. tonsa & Invert & $5 \mathrm{~d}$ Developmental Rate & $\mathrm{EC} 50=66$ & $\mathrm{EC}_{10}=10$ & Wollenberger et al. [20] \\
\hline & & D. rerio & Fish & $\begin{array}{l}\text { ELS 24-48 h Tail Extension, } \\
\text { Coagulated Egss, Edema }\end{array}$ & 1000 & 330 & An et al. [21] \\
\hline \multirow[t]{2}{*}{ Propylparaben } & Preservative & D.magna & Invert & 7 d Growth, Reproduction & 400,6000 & & Dobbins et al. [16] \\
\hline & & Pimephales promelas & Fish & 7 d Growth & 2500 & & Dobbins et al. [16] \\
\hline
\end{tabular}


Nordic Cooperation on Green Public Procurement published the The First Set of Criteria Examples [23]. One of the groups included in the guideline covers hair shampoo, cream soaps/body shampoo and solid and liquid soap for professional use. Disinfectant soaps are not covered. One of the criteria is bioaccumulation or food chain exposure and hazardous effects on aquatic organisms.

In conclusion, safety evaluations for most surfactants in fresh water, and even more so in saltwater environments should be considered limited and preliminary in nature. There is therefore an obvious need of more toxicity data for different surfactants [24]. Thus, this paper aimed to characterize chemical characteristics and acute aquatic toxicity to D. magna and C. dubia of seven commercial PCDs collected from the hotels located in different countries. Based on ecotoxicological data obtained in synthetic aquatic media prepared based on the dilution factor in real wastewater samples, hazard score of each PCD was defined according to EC Directive on Safety of Chemicals (93/67/EC).

\section{Material and Methods}

\subsection{Sample Collection and Solutions}

The PCD samples were collected from different Hotels classified with 3-5 stars located in different countries. Four samples were shampoos while three samples were shower gels. No indication about their hazard class of ecotoxicity to aquatic organisms was present on the samples. All samples were first dissolved in 500-1000 mL distilled water and then diluted for having geometrical varying concentrations for $\mathrm{EC}_{50}$ determinations. Diluted samples were stored at +4 cooled during chemical and ecotoxicological characterization.

\subsection{Analytical Methods}

Because the ingredients of some samples tested were not clarified or their chemicals abstract numbers were lacking to compare with the data sets from the literature, organic content of the samples were defined with the standard cumulative parameter to be COD or TOC in this study.

TOC was measured using a Schimadzu TOC analyzer (6KVA model) at Central Laboratory of Namık Kemal University (NABILTEM). COD experiments were performed according to Standard Methods [25]. $\mathrm{pH}$ was measured using a WTW 3110 model pH-meter.

Absorbance spectra of $\mathrm{PCD}_{\mathrm{s}}$ were determined using a Schimadzu Spectrophotometer (LAMDA 1800 model). As related to aroma city of the organics supposed to be present in the sample solutions absorbance values at 254 and $280 \mathrm{~nm}$ wavelengths were reported.

\subsection{Ecotoxicity Tests}

Acute toxicity of seven commercial PCDs was assessed on two freshwater crustaceans D. magna and C. dubia which are two primary consumers in the aquatic chain. D. magna were inoculated in a temperature constant vivarium at NKU Environmental Engineering Department's Laboratory according to ISO method 6341 [26]. The $\mathrm{pH}$ of the feeding solutions was kept at 8.0 and the total hardness was 250 mg. $\mathrm{L}^{-1}$ (as $\mathrm{CaCO}_{3}$ ). Tests were performed in the dark at 20 ${ }^{\circ} \mathrm{C}$. For aqueous solution, 5 concentrations in a geometrical series were tested in the concentration range. New born daphnids $(<24 \mathrm{~h})$ were exposed to freshly prepared PCD solutions for 24 and $48 \mathrm{~h}$. Experiments were performed as quadruplicate and 5 daphnids were tested in each replicate.

C. dubia cists were kindly provided from another laboratory and incubated at constant temperature room for $48 \mathrm{~h}$ in standard solutions for having nauplii. They, than, were inoculated in the constant room temperature to perform acute toxicity tests with new born daphnids ( $<24 \mathrm{~h}$ aged). All vivarium and experimental procedures were the same with $D$. magna [26].

Acute toxicity was assessed by means of immobilization percentage determined by dividing the number of immobilized organisms in four replicate to total 20 number of test organisms.

\section{Results}

\subsection{Chemical Characterization}

Results of $\mathrm{pH}, \mathrm{COD}$ and TOC measurements of PCDs are given in Table 3 . The ratio between TOC and COD indicated low biodegradability of all PCDs [27]. Absorbance curves of $\mathrm{PCD}_{\mathrm{s}}$ are shown in Figure 1. According to this figure Shower gel 2 only showed the peak value. Absorbance values of all other detergent except Shampoo 1 are low. No peaks observed at 254 and $280 \mathrm{~nm}$ wavelengths indicated the presence of long chain chemicals instead of aromatic structures in the sample solutions.

Table 3. Chemical analysis of the PCDs studied.

\begin{tabular}{|c|c|c|c|c|}
\hline $\begin{array}{c}\text { PCDs } \\
\text { (Dilution Rate, } \\
\mathrm{mL} \text { PCD/mL distilled } \\
\text { water) }\end{array}$ & $\mathrm{pH}$ & $\begin{array}{c}\mathrm{COD} \\
\left(\mathrm{mg} \mathrm{L}^{-1}\right)\end{array}$ & $\begin{array}{c}\text { TOC } \\
\left(\mathrm{mg} \mathrm{L}^{-1}\right)\end{array}$ & TOC/COD \\
\hline Shampoo 1 (1/1000) & 6.13 & 335 & 81 & 0.242 \\
\hline Shampoo 2 (1/1000) & 6.15 & 270 & 53 & 0.196 \\
\hline Shampoo 3 (1/1000) & 6.32 & 155 & 39 & 0.251 \\
\hline Shampoo 4 (1/1000) & 6.30 & 260 & 59 & 0.226 \\
\hline Shower Gel 1 (1/1000) & 6.26 & 270 & 53 & 0.196 \\
\hline Shower Gel 2 (1/500) & 5.75 & 230 & 47.5 & 0.206 \\
\hline Shower Gel 3 (1/1000) & -- & 190 & 38 & 0.200 \\
\hline
\end{tabular}




\subsection{Toxicity Results of PCDs}

Immobilization percentiles of D. magna exposed to PCDs are shown in Figure 2 while Figure 3 illustrates the immobilization percentiles of $C$. dubia. $\mathrm{EC}_{50}$ values of $D$. magna and $C$. dubia calculated by the PROBIT program are shown in Table 4 and Table 5 respectively. The results of PROBIT analysis remain within $95 \%$ confidence intervals (CI) and they displayed high regression coefficients. $\mathrm{EC}_{50}$ values ranged from 10.49 to $50.59 \mathrm{mg} . \mathrm{L}^{-1}$ for $D$. magna and from 7.768 to $44.82 \mathrm{mg} . \mathrm{L}^{-1}$ for $C$. dubia. These data confirm the findings on some detergents $[3,28]$.

$\mathrm{EC}_{50}$ values of $C$. dubia were found to be lower compared to the values calculated for the data sets of D. magna. These results indicated that $C$. dubia exhibited more sensitivity to the tested products than D. magna.

The results of acute toxicity tests performed with $D$. magna can be ranked in the following order:

- Shampoo 3>Shower Gel 1>Shampoo 4> Shampoo 1>

Shower Gel 3> Shampoo 2> Shower Gel 2,

while this ranking changed in the case of $C$. dubia acute toxicity test results as:

- Shampoo 4>Shampoo 3>Shampoo 1>Shampoo $2>$ Shower Gel 1 $>$ Shower Gel 2>Shower Gel 3

Toxicity units $\left(\mathrm{TU}=100 / \mathrm{EC}_{50}\right)$ were also determined for the studied PCDs as shown in Figure 4.

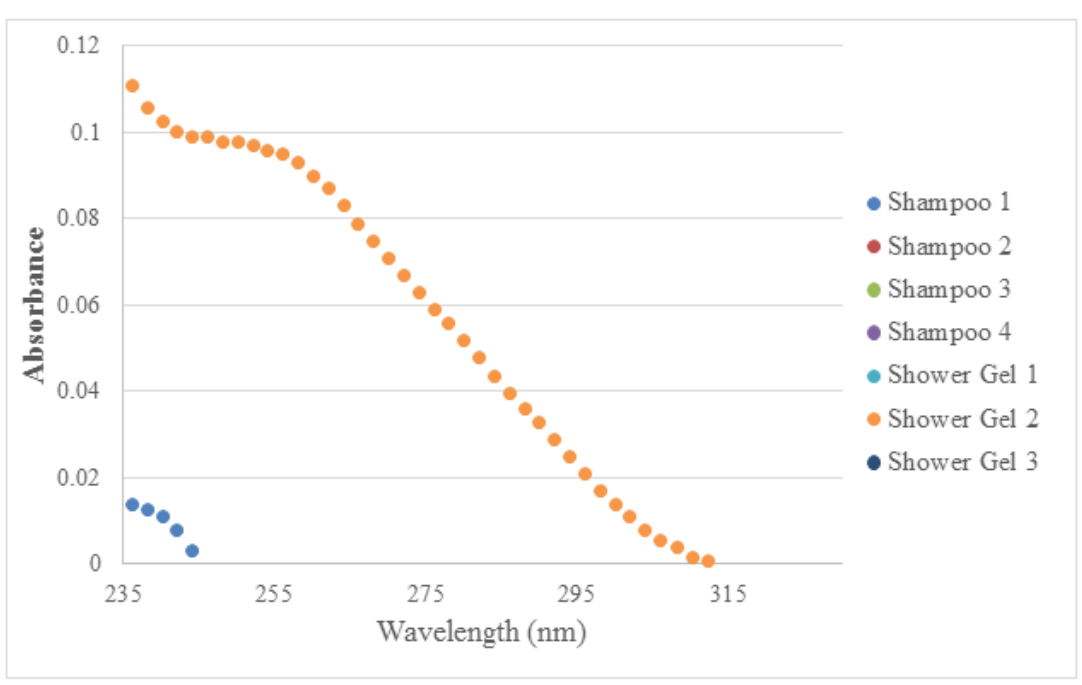

Figure 1. Absorbance curves of personal care detergents studied

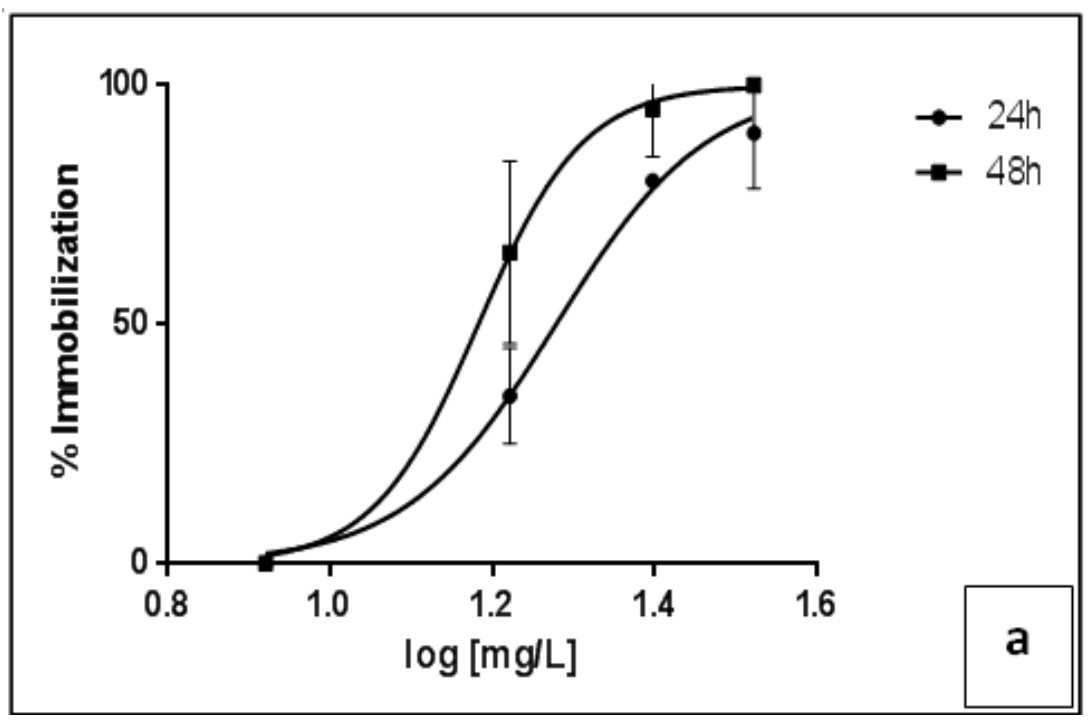



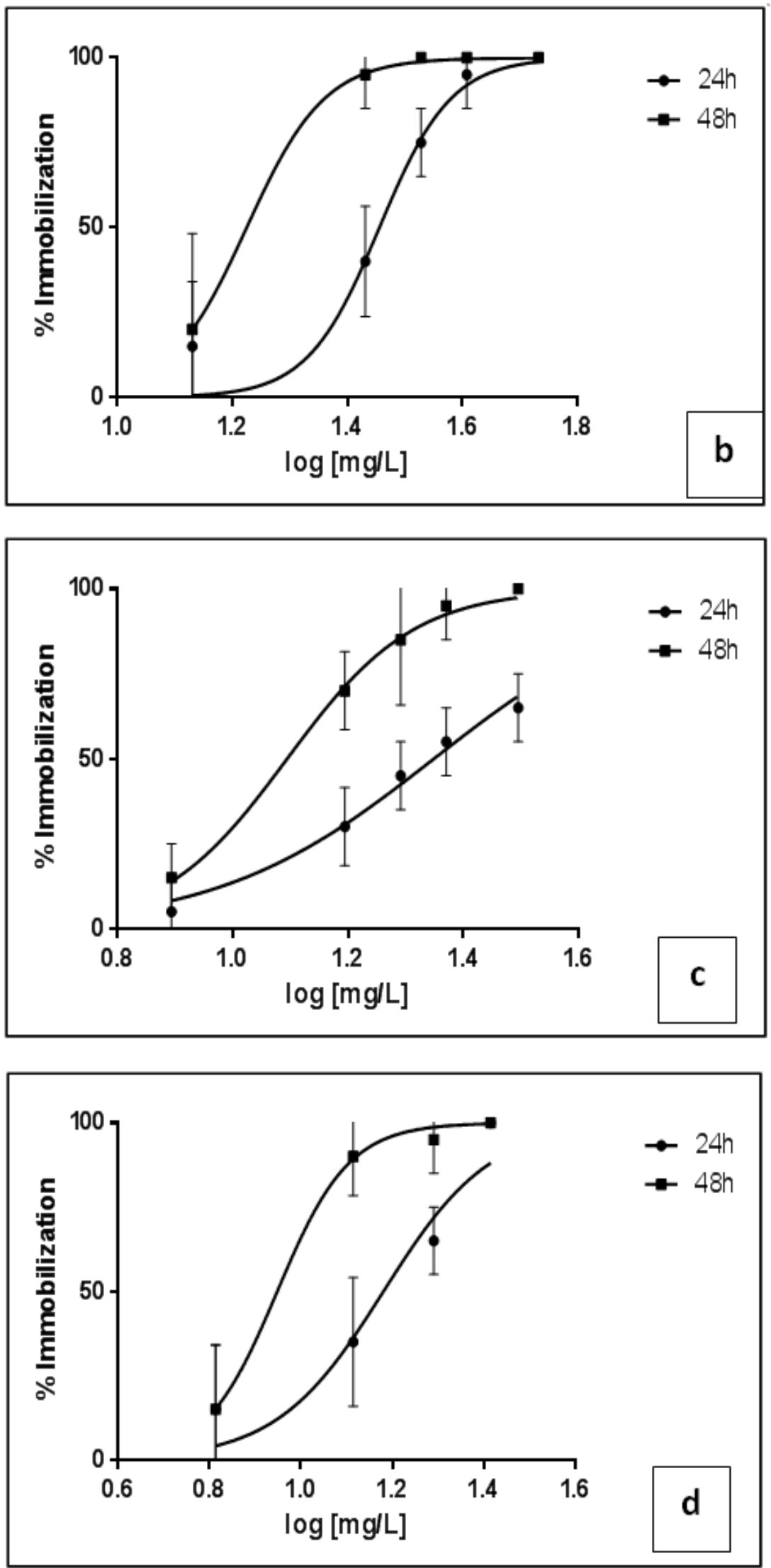

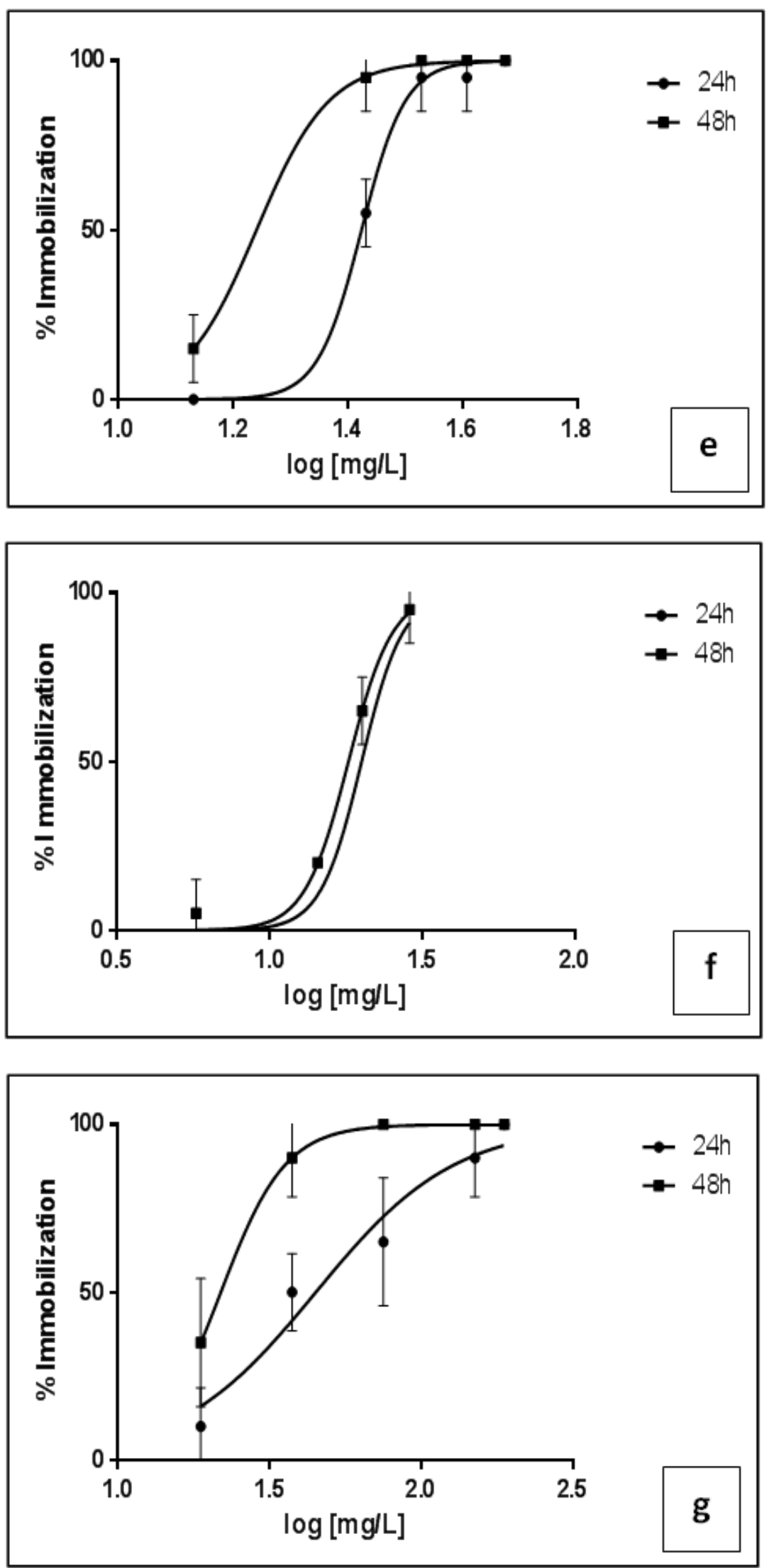

Figure 2. Immobilization percentiles profiles determined using the PROBIT for the data sets of D. magna (Shampoo 1(a), 2(b), 3(c), 4(d) and Shower gel 1(e), 2(f), 3(g) ) 

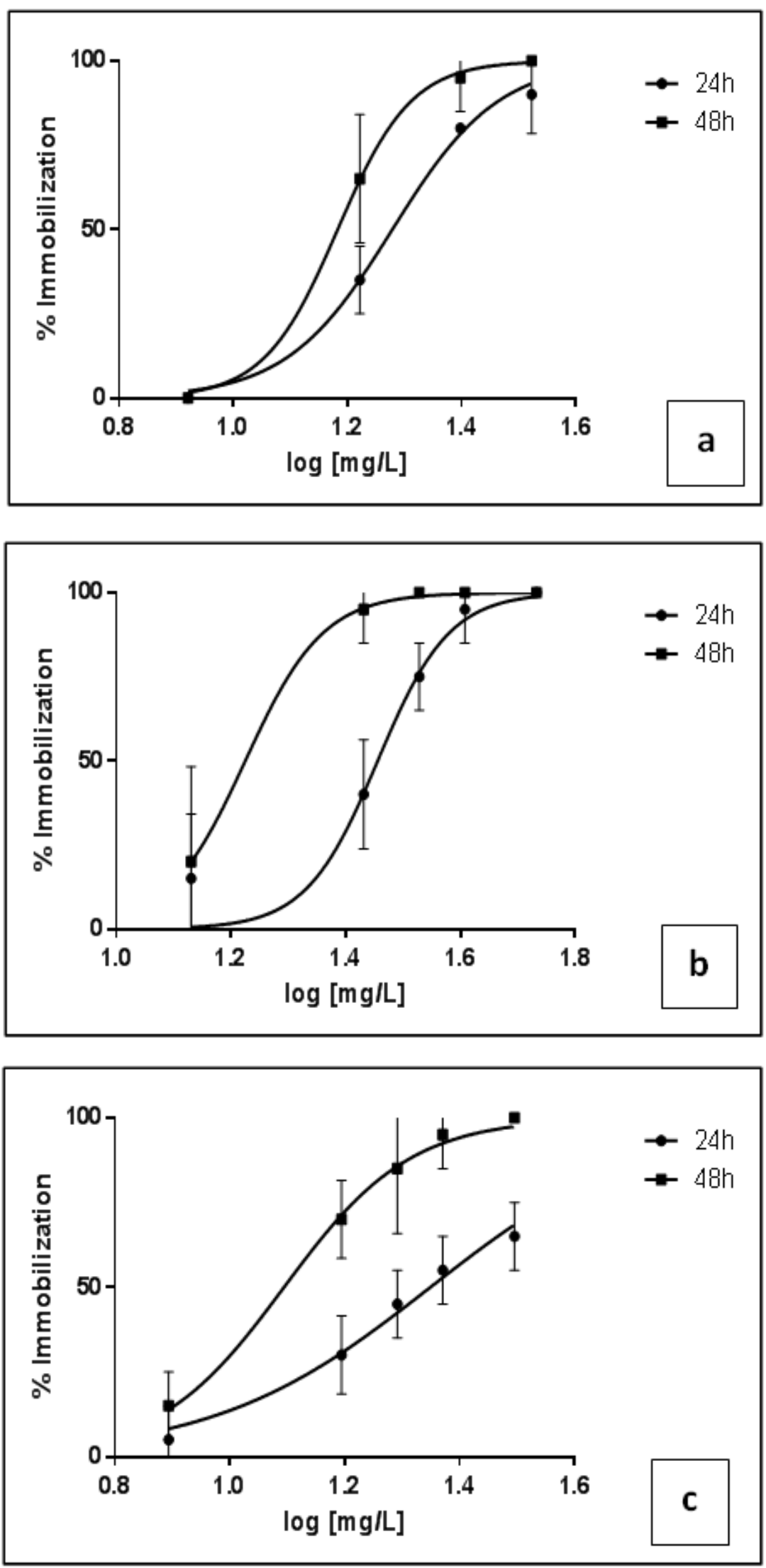

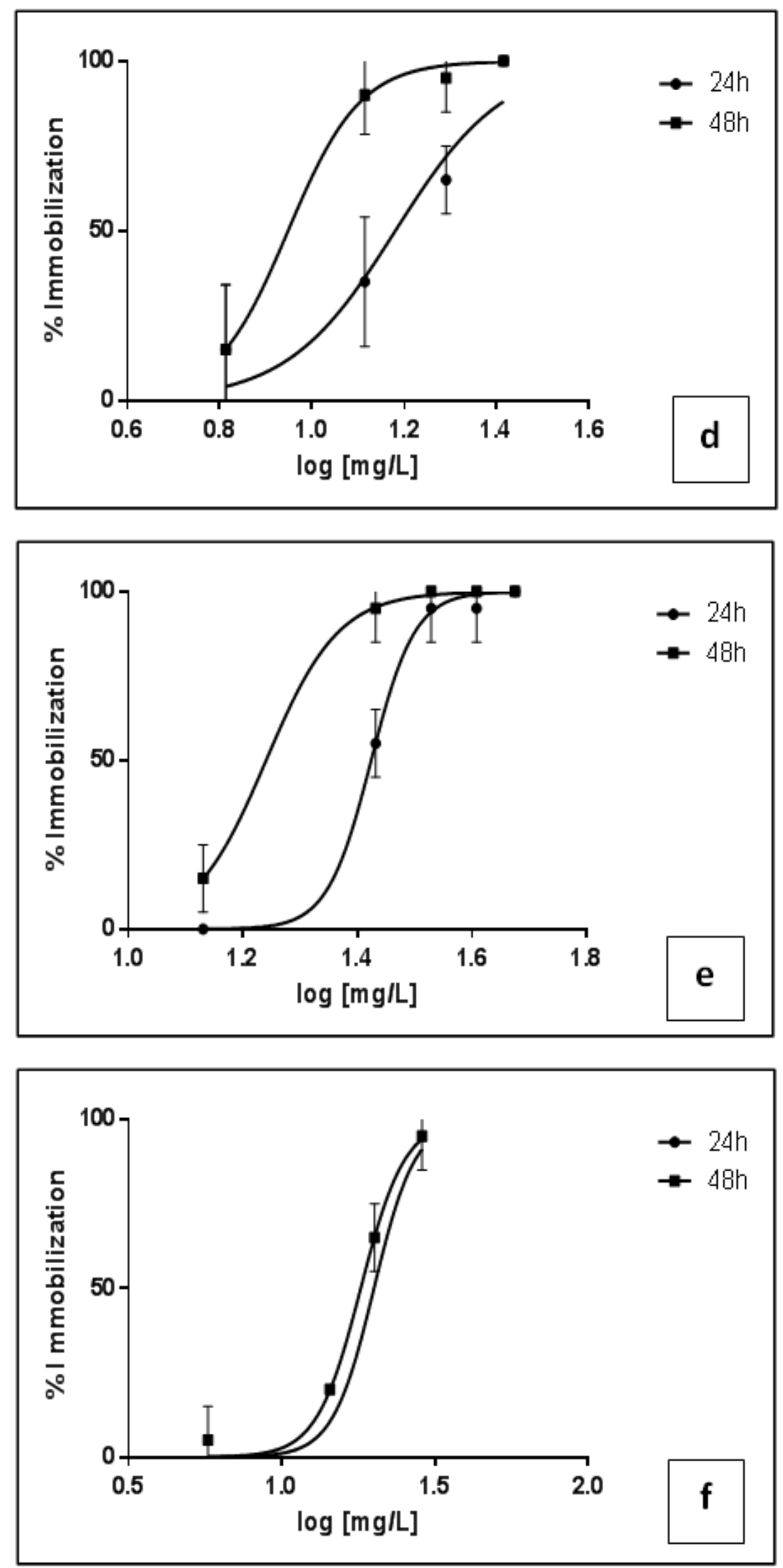


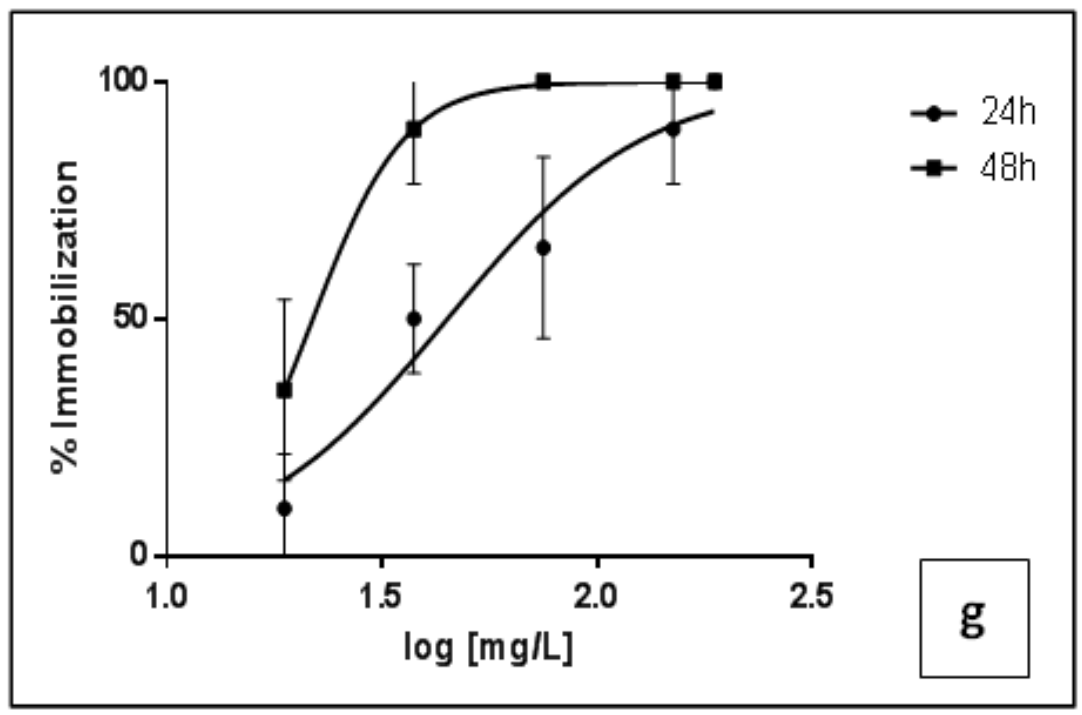

Figure 3. Immobilization percentiles profiles determined using the PROBIT for the data sets of C. dubia. (Shampoo 1(a), 2(b), 3(c), 4(d) and Shower gel 1(e), 2(f), 3(g))

Table 4. The values of $\mathrm{EC}_{50}$ and $95 \%$ confidence intervals for $D$. magna $\left[\mathrm{R}^{2}\right.$ : Regression values $]$; (Confidence intervals)

\begin{tabular}{|c|c|c|c|c|}
\hline D. magna & \multicolumn{5}{|c|}{ EC $_{\mathbf{5 0}}$ (mg. $^{-\mathbf{1}}$ ) } \\
\hline Sample & $24 \mathrm{~h}$ & $95 \% \mathrm{CI}$ & $48 \mathrm{~h}$ & $95 \%$ CI \\
\hline Shampoo 1 & $35.14[0.99]$ & $(27.74-44.51)$ & $25.3[0.98]$ & $(21.08-30.29)$ \\
\hline Shampoo 2 & $45.65[0.985]$ & $(38.81-53.69)$ & $31.93[0.916]$ & $(21.56-47.27)$ \\
\hline Shampoo 3 & $30.99[0.992]$ & $(24.68-38.91)$ & $10.49[0.999]$ & $(9.228-11.92)$ \\
\hline Shampoo 4 & $30.4[0.998]$ & $(29.65-31.16)$ & $22.14[1.00]$ & $(14.78-24.69)$ \\
\hline Shower Gel 1 & $31.7[0.99]$ & $(28.95-34.72)$ & $19.1[1.00]$ & $(39.12-48.12)$ \\
\hline Shower Gel 2 & $50.59[0.994]$ & $(47.50-53.88)$ & $43.38[0.9839]$ & $(25.87-28.12)$ \\
\hline Shower Gel 3 & $33.13[0.996]$ & $(32.35-33.93)$ & $26.97[0.992]$ & \\
\hline
\end{tabular}

Table 5. The values of EC50 and $95 \%$ confidence intervals for $C$. dubia $\left[\mathrm{R}^{2}\right.$ : Regression values $]$

\begin{tabular}{|c|c|c|c|c|}
\hline \multirow{2}{*}{$\begin{array}{c}\text { C. magna } \\
\text { Sample }\end{array}$} & \multicolumn{4}{|c|}{$\mathrm{EC}_{50}\left(\mathrm{mg} . \mathrm{L}^{-1}\right)$} \\
\hline & $24 \mathrm{~h}$ & $95 \% \mathrm{CI}$ & $48 \mathrm{~h}$ & $95 \% \mathrm{CI}$ \\
\hline Shampoo 1 & $18.99[0.997]$ & $(17.26-20.88)$ & $15.23[0.999]$ & $(14.15-16.39)$ \\
\hline Shampoo 2 & 28.56 [0.959] & $(24.98-32.64)$ & $16.78[1.00]$ & $(16.30-17.28)$ \\
\hline Shampoo 3 & $22.32[0.985]$ & $(20.17-24.70)$ & 12.42 [0.997] & $(11.50-13.41)$ \\
\hline Shampoo 4 & $15.14[0.93]$ & $(9.631-23.80)$ & $8.868[1.00]$ & $(7.768-10.12)$ \\
\hline Shower Gel 1 & 26.52 [0.997] & $(25.68-27.38)$ & $17.39[1.00]$ & $(16.90-17.89)$ \\
\hline Shower Gel 2 & $19.99[0.9828]$ & $(17.08-23.38)$ & 18.1 [0.9952] & $(16.55-19.78)$ \\
\hline Shower Gel 3 & $44.82[0.9597]$ & $(30.33-66.24)$ & $21.82[1.00]$ & $(21.55-22.09)$ \\
\hline
\end{tabular}




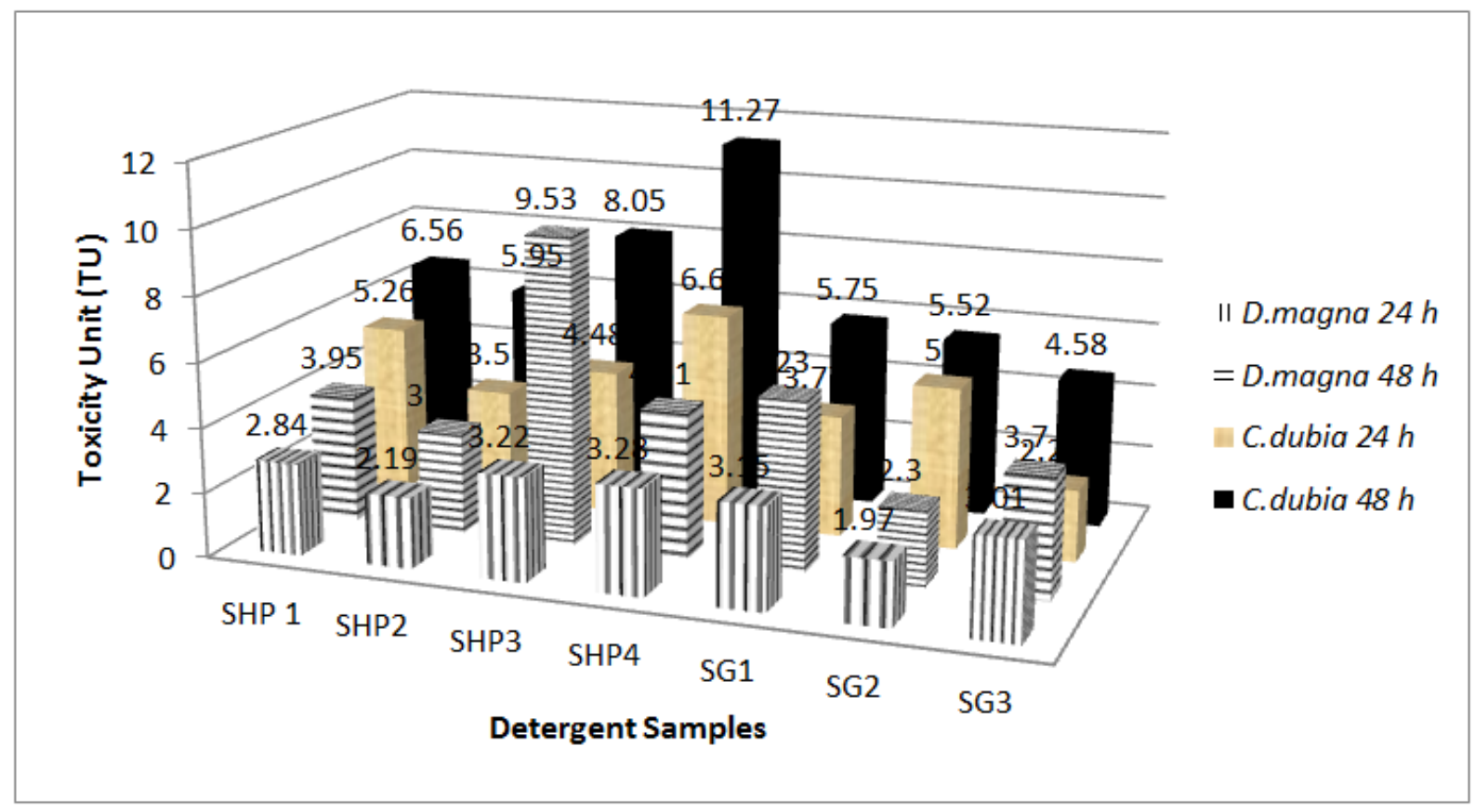

Figure 4. Toxicity unit values as determined using the PROBIT analysis (SHP: Shampoo products; SG: Shower gel)

\subsection{Hazard Score Definition}

Hazard scores of the studied PCDs are evaluated according to EC Directive (93/67/EEC) [29] are given in Table 6. This hazard classification is based on $\mathrm{EC}_{50}$ values and namely chemicals are classified in four classes. When $\mathrm{EC}_{50}$ values calculated using the PROBIT analysis for $\mathrm{PCD}_{\mathrm{s}}$ (Tables 4-5) were compared with hazard classes shown in Table 6, all PCDs were classified as harmful to aquatic organisms (Hazard score was found to be 3 ) for both 24 and $48 \mathrm{~h}$ exposure times except that hazard scores were found to be 2 (Toxic for aquatic organisms) for $C$. dubia exposed to Shampoo 4 for $48 \mathrm{~h}$.

Table 6. Classification of hazardous substances according to 93/67/EC Directive [15]

\begin{tabular}{|c|c|c|}
\hline $\mathbf{E C}_{\mathbf{5 0}}\left(\mathbf{m g ~ \mathbf { L } ^ { - 1 }}\right)$ & Risk Classification & $\begin{array}{c}\text { Hazard } \\
\text { Score }\end{array}$ \\
\hline $\mathrm{EC}_{50}<1$ & $\begin{array}{c}\text { Very toxic for aquatic } \\
\text { organisms }\end{array}$ & 1 \\
\hline $1<\mathrm{EC}_{50}<10$ & $\begin{array}{c}\text { Toxic for aquatic } \\
\text { organisms }\end{array}$ & 2 \\
\hline $11<\mathrm{EC}_{50}<100$ & $\begin{array}{c}\text { Harmful to aquatic } \\
\text { organisms }\end{array}$ & 3 \\
\hline $\mathrm{EC}_{50}>100$ & Not classifiable & 4 \\
\hline
\end{tabular}

\section{Discussion}

Our results of acute toxicity tests can be evaluated in the range of chemicals shown in Table 4. Although the PCDs tested at the estimated dilutions in synthetic solutions resulted in harmful to aquatic organisms in this study one can estimate that there can be adsorption, sedimentation, biodegradation factors in the sewage systems and WWTPs to decrease the concentration of PCDs before discharge $[3,30]$. Anyway, The PCDs have become spread in sewage, in the effluents of $\mathrm{WWTP}_{\mathrm{s}}$, rivers, sludges and soils via sludges amended on [31].

From the point of Eco-labeling, as all $\mathrm{EC}_{50}$ values of acute toxicity tests shown in Tables 4 and 5 were calculated over $10 \mathrm{mg} . \mathrm{L}^{-1}$, except Shampoo 4 (after $48 \mathrm{~h}$ of exposure), none of the products are assessed to be pretty acceptable either by the EU [22] or by the Nordic classification [23] because of lacking information of ingredients that requires to perform chronic tests. Our results can be accepted as the base to perform further evaluations and tests in this manner.

\section{Conclusions}

PCDs collected from different hotels located in different countries were characterized for biodegradability and acute toxicity to D. magna and C. dubia.

- Ratio between TOC and COD was found to be very low (approx.. 0.2) indicating low biodegradability of the tested chemicals. This fact emerges the need of advanced treatment processes.

- The results of acute toxicity tests showed that both species displayed different behaviour when exposed to the PCDs. C. dubia was found to be more sensitive than D. magna.

- According to $\mathrm{EC}_{50}$ values evaluated for hazard classification almost all PCDs tested were assessed to be Harmful to aquatic organisms (Hazard score was found to be 3) except shampoo 4 and shampoo 3 which were found to be toxic for aquatic organisms 
(Hazard score 2) for C. dubia and D. magna exposed to the PCDs for $48 \mathrm{~h}$.

- $\mathrm{PCD}_{\mathrm{s}}$ are the chemicals of concern that their consumption has been increasing with the improving life quality standards. Although their fate and transformation in sewage and treatment systems have been documented they widely occur in the environmental compartments. Thus, the results obtained in this study show that this group of pollutants should be handled carefully before entering the aquatic environment.

\section{REFERENCES}

[1] A.S. Sobrino-Figueroa, Evaluation of Oxidative Stress and Genetic Damage Caused by Detergents in the Zebrafish Danio rerio (Cyprinidae). Comp. Bioch. and Phys. Part A, 2013, 165, 528--532.

[2] G.G. Ying, Fate, Behaviour and Effects of Surfactants and Their Degradation Products in the Environment. Environ. Int. 2006, 32, 417--431.

[3] J. M. Brausch, G. M. Rand, A Review of Personal Care Products in the Aquatic Environment: Environmental Concentrations and Toxicity. Chemosphere. 2011, 82, 1518--1532.

[4] T. Gouin, R. Van Egmond, O.R. Price, J.E.N. Hodges, Prioritising Chemicals Used in Personal Care Products in China for Environmental Risk Assessment: Application of the RAIDAR model. Environ. Poll. 2012,165, 208--214.

[5] A.K. Mungray, P. Kumar, Occurrence of Anionic Surfactants in Treated Sewage: Risk Assessment to Aquatic Environment. J. of Haz. Mat. 2008, 160, 362--370.

[6] M.A. Lewis, Chronic and Sublethal Toxicities of Surfactants to Aquatic Animals: A Review and Risk Assessment. Water Res. 1991, 25, 101--103.

[7] R. Pedrazzani, E. Ceretti, I. Zerbini, R. Casale, E.Gozio, G. Bertanza, U. Gelatti, F. Donota, D. Feretti, Biodegradability, Toxicity and Mutagenicity of Detergents: Integrated Experimental Evaluation. Ecotox. and Environ. Saf. 2012, 84, 274--281

[8] B. Nunes, F. Carvalho, L. Guilhermino, Effects of Widely Used Pharmaceuticals and a Detergent on Oxidative Stress Biomarkers of the Crustacean Artemia parthenogenetica. Chemosphere. 2006, 62, 581--594.

[9] L.L. Dobbins, S. Usenko, R.A. Brain, B.W. Brooks, Probabilistic Ecological Hazard Assessment of Parabens Using Daphnia magna and Pimephales promelas. Environ. Tox. Chem. 2009, 28, 2744-2753.

[10] D.R. Orvos, D.J. Versteeg, J. Inauen, M. Capdevielle, A. Rothenstein, Cunningham V. Aquatic toxicity of triclosan. Environmental Toxicology Chemistry. 2002, 21, 1338--1349.

[11] H. Ishibashi, N. Matsumura, M. Hirano, M. Matsuoka, H. Shiratsuchi, Y. Y. Ishibashi, Y.T. Akao, K. Arizono, Effects of Triclosan on the Early Life Stages and Reproduction of Medaka Oryzias latipes and Induction of Hepatic vitellogenin.
Aquatic Toxicology. 2004, 67, 167--179.

[12] L.H. Yang, G.G. Ying, H.C. Su, J.L. Stauber, M.S. Adams, M.T. Binet, Growth Inhibiting Effects of 12 Antibacterial Agents and Their Mixtures on the Freshwater Microalgae Pseudokirchneriella subcapitata. Environmental Toxicology Chemstry. 2008, 27, 1201--1208.

[13] K.W. Schramm, A. Kaune, B. Beck, W. Thumm, A. Behechti, A. Kettrup, P. Nickolova, Acute Toxicities of Five Nitromusk Compounds in Daphnia, Algae and Photoluminescent Bacteria. Water Resource. 1996, 30, 2247--2250.

[14] M. Breitholtz, L. Wollenberger, L. Dinan, Effects of Four Synthetic Musks on the Life Cycle of the Harpacticoid Copepod Nitocra spinipes. Aquatic Toxicology. 2003, 63, 103--118

[15] I. Bazin, A. Gadal, E. Touraud, B. Roig, Hydroxy Benzoate Preservatives (parabens) in the Environment: Data for Environmental Toxicity Assessment. In: Fatta-Kassinos, D., Bester, K., Kummener, K. (Eds.), Xenobiotics in Urban Water Cycle: Mass Flows, Environmental Processes, Mitigation and Treatment Strategies. Environmental Pollution. Springer, Netherlands. 2010.

[16] L.L. Dobbins, S. Usenko, R.A. Brain, B.W. Brooks, Probabilistic Ecological Hazard Assessment of Parabens Using Daphnia magna and Pimephales promelas. Environmental Toxicology Chemistry. 2009, 28, 2744--2753.

[17] E.B. Dussault, V.K. Balakrishnan, E. Sverko, K.R. Solomon, P.K. Sibley, Toxicity of Human Pharmaceuticals and Personal Care Products to Benthic Invertebrates. Environmental Toxicology Chemstry. 2008, 27, 425--432.

[18] B.A. Wilson, V.H. Smith, J.F. Denoyelles, C.K. Lorive, Effects of Three Pharmaceuticals and Personal Care Products on Natural Freshwater Algal Assemblages. Environmental Science Technology. 2003, 37, 1713--1719.

[19] M.E. DeLorenzo, J. Fleming, Individual and Mixture Effect of Selected Pharmaceuticals and Personal Care Products on the Marine Phytoplankton Species Dunaliella tertiolecta. Arch. Environmental Contamination Toxicology. 2008, 54, 203--210

[20] L. Wollenberger, M. Breitholtz, K.O. Kusk, B.E. Bengtsson, Inhibition of Larval Development of the Marine Copepod Acartia tonsa by Four Synthetic Musk Substances. Science Total Environment. 2003, 305, 53--64.

[21] J. An, Q. Zhou, Y. Sun, Z. Xu, Ecotoxicological Effects of Typical Personal Care Products on Seed Germination and Seedling Development of Wheat (Triticum aestivum L.). Chemosphere. 2009, 76, 1428--1434.

[22] EC, 2007. Commission Decision 2007/506/EC of 21 June 2007 Establishing the Ecological Criteria for the Award of the Community Eco-label to Soaps, Shampoos and Hair Conditioners (notified under document number C. 2007, 3127.

[23] EC COUNCIL DIRECTIVE of 27 June 1967 on the Approximation of Laws, Regulations and Administrative Provisions Relating to the Classification, Packaging and Labelling of Dangerous Substances (67/548/EEC). 1967.

[24] H. Yamamoto, I. Tamura, Y. Hirata, J. Kato, K. Kagota, S. 
Katsuki, A. Yamamoto, Y. Kagami, N. Tatarazako, Aquatic Toxicity and Ecological Risk Assessment of Seven Parabens: Individual and Additive Approach. Sci. of the Tot. Environ. 2011, 410-411, 102--111.

[25] American Public Health Association (APHA), Water Environment Federation (WEFW), Standard Methods for the Examination of Water and Wastewater, American Public Health Association, Washington, DC, 1998.

[26] International Organization for Standardizations (ISO), Water Quality: Determination of the Inhibition of the Mobility of Daphnia magna straus (Cladocera, Crustacea)-Acute Toxicity Test, ISO 6341, Geneva, Switzerland. 2012.

[27] M.T. Garcia, E. Campos, I. Ribosa, Biodegradability and Ecotoxicity of Amine Oxide Based Surfactants. Chemosphere. 2007, 69, 1574--1578.
[28] D.I.Çifçi, O. Kizek, F. Ekmekyapar, S. Meriç, Impact Assessment and Risk Evaluation of a Set of Personal Care Detergents. VII. International Symposium on Ecology and Environmental Problems. Antalya-Side, Turkey. 2013, 135.

[29] EEC (1993) Commission Directive (93/67/EEC) of 20 July 1993 Laying Down the Principles for Assessment of Risks to Man and the Environment of Subtances Notified in Accordance with Council Directive 67/548/EEC.

[30] D.Göran, G. Herger, Determination of detoxification to Daphnia magna of Four Pharmaceuticals and Seven Surfactants by Activated Sludge. Chemosphere. 2012, 88, 459--466.

[31] I. Christina, D. Kosma, A. Lambropoulou, A. Triantafyllos, A. Albanis, Investigation of PPCPs in Wastewater Treatment Plants in Greece: Occurrence, Removal and Environmental Risk Assessment. Science of the Total Environment. 2014, 466--467 421-438 